\title{
Demonstration of an epitope of the transferrin receptor in human cervical epithelium-a potentially useful cell marker
}

\author{
JM LLOYD, T O’ DOWD,† M DRIVER, ${ }^{*}$ DEH TEE
}

From the Departments of Immunology and *Morbid Anatomy, King's College Hospital Medical School, Denmark Hill, and the †Department of Obstetrics and Gynaecology, Dulwich Hospital and King's College Hospital, London SE5

SUMMARY The distribution of an epitope of the transferrin receptor in the human uterine cervical epithelium has been investigated. Immunohistochemical staining, both immunofluorescent and immunoperoxidase, was performed on biopsy specimens and cytological samples from normal, dysplastic, and neoplastic cervical epithelia using the monoclonal OKT9 antibody. The results of staining 145 cervical biopsy specimens with OKT9 showed widespread staining in all malignant epithelia and most severely dysplastic epithelia. No such staining was seen in either normal epithelia or in mildly dysplastic epithelia apart from the staining of the basal cell layer in some normal epithelia. The incidence of staining in the 50 cervical cytocentrifuge preparations was not as high as that in the 145 tissue sections.

The potential role of the OKT9 antibody in both the screening of cervical cytocentrifuge preparations and the prediction of malignancy is discussed. The antibody is considered to be of more value in the examination of biopsy material than of cytocentrifuge preparations.

The monoclonal antibody OKT9, raised against human leukaemia cells, recognises an epitope of the transferrin receptor.' This receptor is thought to have an essential role in the transport of iron across the cell membrane and has been detected on cells which have a large iron requirement such as reticulocytes and placental syncytiotrophoblast. ${ }^{23}$ In addition to this the receptor has a widespread distribution on transformed human cell lines ${ }^{4}$ and an association with cell proliferation and activation. ${ }^{57}$ The transferrin receptor has been found on breast cancer cells ${ }^{89}$ and antitransferrin receptor antibody inhibits human tumour cell growth in mice. ${ }^{10}$ This work on proliferating and malignant cells encouraged us to investigate the distribution of the transferrin receptor in the human uterine cervix. In this study biopsy specimens and cytological samples from normal, dysplastic, and malignant epithelia were examined using the OKT9 antibody in immunofluorescence and immunoperoxidase techniques.

Accepted for publication 26 October 1983

\section{Material and methods}

\section{IMMUNOHISTOLOGICAL REAGENTS}

The three monoclonal antibodies were obtained from Ortho Diagnostic Systems Ltd: OKT9 (recognises the transferrin receptor); OKT4 (identifies human inducer/helper $\mathrm{T}$ lymphocyte subclass); and OKT8 (identifies human suppressor/cytotoxic $T$ lymphocyte subclass). Peroxidase and fluorescein isothiocyanate conjugated goat antimouse IgG antibodies were obtained from TCS, Slough,. Bucks. Diaminobenzidine tetrahydrochloride was obtained from Sigma Chemical Co.

TISSUE SECTIONS (CERVICAL BIOPSY SPECIMENS) Fresh biopsy tissue was obtained from a referral colposcopy clinic at Dulwich Hospital. Other fresh cervical tissue was obtained from either hysterectomy or cone biopsy specimens at King's College Hospital or Dulwich Hospital. Placenta from normal term pregnancies was also collected. All tissue was snap frozen in liquid nitrogen within $1 \mathrm{~h}$ of collection and stored at $-80^{\circ} \mathrm{C}$ before cryostat sectioning at $5 \mu \mathrm{m}$. The sections were air dried for $30 \mathrm{~min}$ and stained 
immediately by the immunofluorescence procedure (see below).

CYTOCENTRIFUGE CELL PREPARATIONS

Cervical scrapes were taken at the colposcopy clinic, and after preparing a smear for cytological evaluation the cells were centrifuged as previously described. ${ }^{16}$ The slides thus prepared were stored at $-80^{\circ} \mathrm{C}$ before immunostaining. The technique used therefore bears similarities to work done on cervical cell imprints, ${ }^{11}$ rather than to work done on unfixed cervical cells in suspension. ${ }^{1213}$

\section{IMMUNOFLUORESCENCE}

Immunofluorescence was performed on frozen sections of fresh cervical biopsies and normal placenta. Sections of tissue were incubated for $60 \mathrm{~min}$ with OKT9 or control antibody (OKT4, OKT8) diluted $1 / 20$ in phosphate buffered saline (PBS). The sections were washed three times for $10 \mathrm{~min}$ each in PBS and incubated for $30 \mathrm{~min}$ in goat antimouse fluorescein isothiocyanate conjugate at a dilution of $1 / 50$ in PBS. The sections were then washed three times for $10 \mathrm{~min}$ each in PBS, mounted in glycerol/ PBS, and examined using a Reichert-Jung Polyvar microscope with a $200 \mathrm{~W}$ mercury vapour lamp, a blue BP 455-490 incident light exciter filter, a DS 500 dichroic mirror, and a blue LP 515 barrier filter. Adjacent sections were stained with haematoxylin and eosin for routine histological diagnosis.

IMMUNOPEROXIDASE

Cell preparations were examined using an indirect immunoperoxidase method. The diagnosis of cervical cytology is based largely on nuclear detail, and immunoperoxidase is more suitable than immunofluorescence for showing the cell nucleus in these preparations.

The prepared slides were incubated for $60 \mathrm{~min}$ with OKT9 or control antibody diluted 1/20 in Tris buffered saline (TBS) (prepared by diluting $0.5 \mathrm{M}$ Tris/ $\mathrm{HCl}$ buffer ( $\mathrm{pH} \mathrm{7.6)} 1 / 10$ in saline). The preparations were washed three times for 10 min each in TBS and incubated for $30 \mathrm{~min}$ in goat antimouse peroxidase conjugate at a dilution of $1 / 50$ in TBS. The slides were then washed three times for $10 \mathrm{~min}$ each in TBS and reacted for $5 \mathrm{~min}$ with diaminobenzidine tetrahydrochloride at $500 \mu \mathrm{g} / \mathrm{ml}$ in 0.2 Tris/ $\mathrm{HCl}$ buffer ( $\mathrm{pH} \mathrm{7.6)}$ containing $0.01 \%$ (v/v) hydrogen peroxide $\left(\mathrm{H}_{2} \mathrm{O}_{2}\right)$. The preparations were washed in tap water for $5 \mathrm{~min}$, stained with haematoxylin, dehydrated in alcohol, cleared in xylene, and mounted in DPX. Endogenous peroxidase is not present in the cells of the ectocervix and therefore did not have to be blocked. Sections of normal human placenta were also examined as controls using this technique.

\section{Results}

PLACENTAL TISSUE

By using both the immunofluorescence and the immunoperoxidase techniques the syncytiotrophoblast was positively labelled with OKT9. The central core of the cytotrophoblast did not stain. This is in agreement with the known distribution of transferrin receptors in the trophoblast. ${ }^{2}$ Neither OKT4 nor OKT8 labelled the sections.

\section{CERVICAL BIOPSIES}

OKT9 antibody was found, using the immunofluorescence technique, on cells from dysplastic epithelia, carcinoma in situ, and invasive carcinoma. The positive staining reaction was seen throughout the thickness of the epithelium and was located both on the cell membrane and in the cytoplasm (Fig. 1). The intensity of fluorescence was not constant and varied not only between sections from different biopsies but also within each section of epithelium.

Little or no staining occurred in the cells from normal epithelia. The only staining seen was localised in the basal cell layers of the epithelium and in areas of immature squamous metaplasia. This staining was of low intensity but was uniformly distributed throughout the basal cell layers.

The results of immunofluorescence labelling of 145 cervical biopsies are summarised in Table 1 . All the tumours and most of the severe dysplasias examined showed widespread positive staining with OKT9. Widespread staining was seen in about half of the moderate dysplasia $(20 / 38)$ and was absent from normal epithelia. About one third of the normal epithelia (15/42) was positively stained in the basal cell layers only. Comparison of the patterns of staining seen in the three categories of dysplasia suggests that there is a positive correlation between the severity of dysplasia and the incidence of widespread positivity.

\section{CYTOCENTRIFUGE CELL PREPARATIONS}

The OKT9 antibody was located using the immunoperoxidase technique on malignant and dyskaryotic cells (Fig. 2). Positive staining was distributed on the cell membrane of intact cells and was visible both on the surface of the cell and as a rim around the cell. No staining was seen on normal epithelial cells.

The results of immunoperoxidase staining of 50 cytocentrifuge preparations with OKT9 are summarised in Table 2. Most malignant and severely dyskaryotic preparations contained positively stained cells, whereas few mildly or moderately dyskaryotic preparations were stained. All normal pre- 


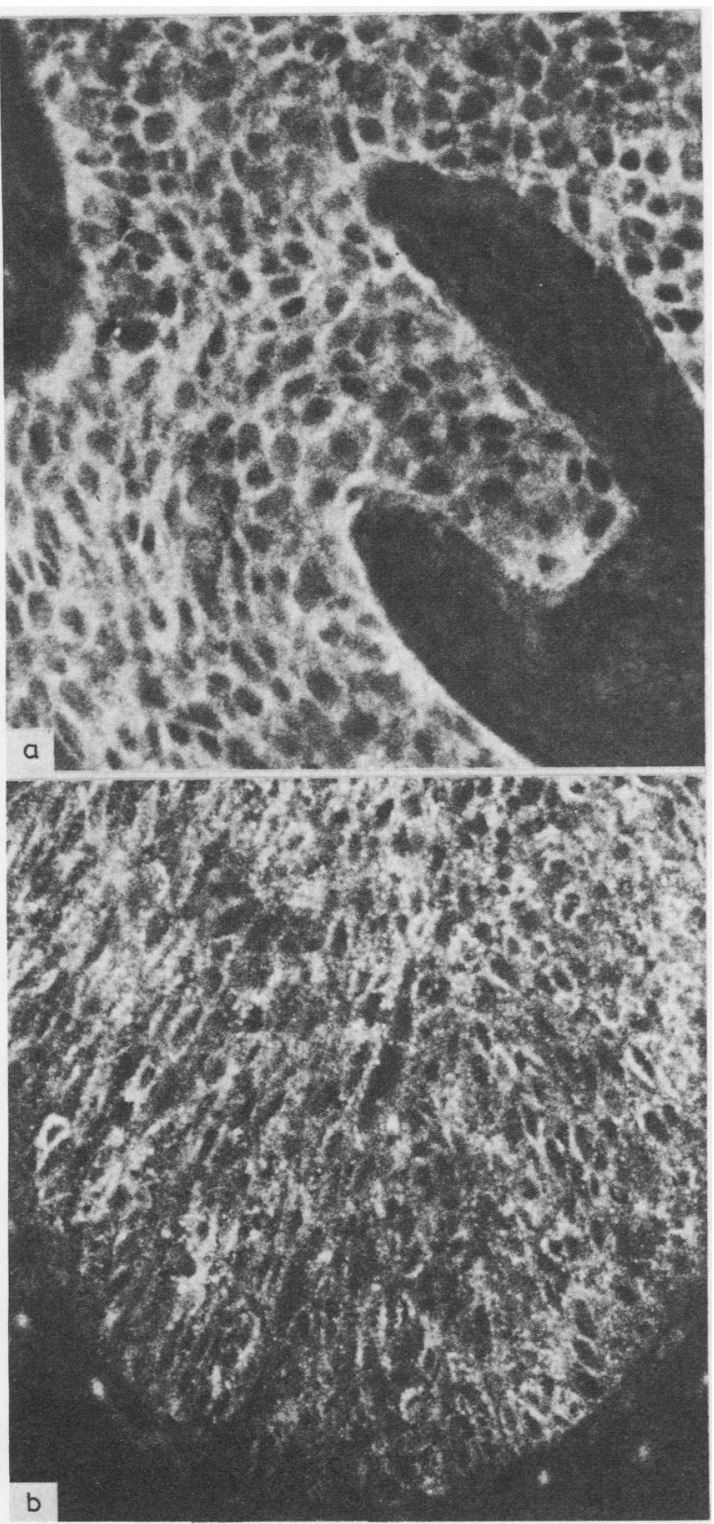

Fig. 1 Immunofuorescence staining of cervical epithelium using OKT9 monoclonal antibody. (a) Invasive squamous cell carcinoma. All tumour cells are intensely stained. $\times$ 200. (b) Dysplastic epithelium. All dysplastic cells are intensely stained. $\times 150$.
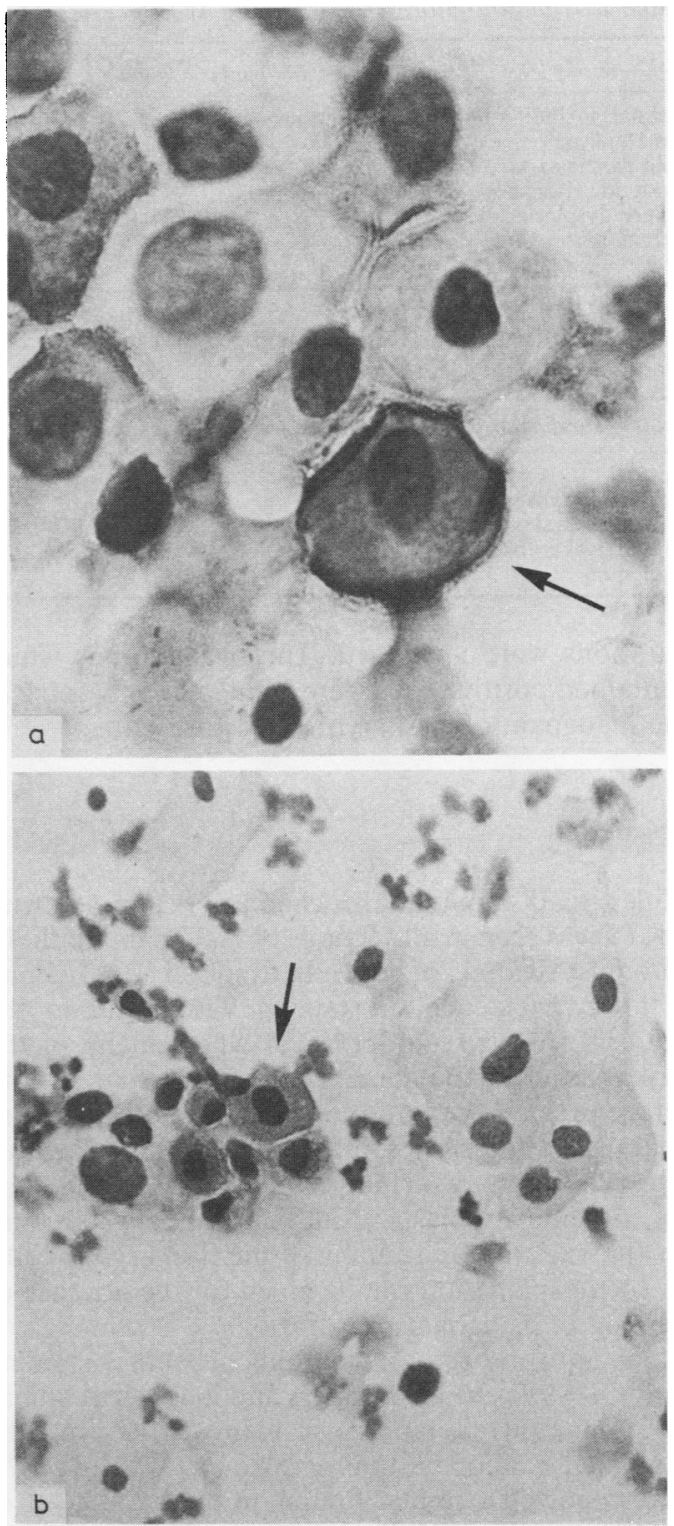

Fig. 2 Immunoperoxidase staining of cervical cytocentrifuge preparations using OKT9 monoclonal antibody. (a) Malignant cervical squamous cells. Arrowed cell shows strong positive staining. $\times 800$. (b) Dyskaryotic and normal cervical squamous cells. Arrowed dyskaryotic cells are positively stained. Other dyskaryotic and normal cells are unstained. $\times 300$. 
Table 1 Immunofuorescence staining of 145 cervical biopsies with OKT9 antibody

\begin{tabular}{|c|c|c|c|c|}
\hline Histological diagnosis of squamous epithelia & Total & Positive staining & Negative staining & Basal layer staining only \\
\hline $\begin{array}{l}\text { Normal, including immature squamous } \\
\text { metaplasia }\end{array}$ & 42 & 0 & 27 & 15 \\
\hline Mild dysplasia & 31 & 5 & 17 & 9 \\
\hline Moderate dysplasia & 38 & 20 & 12 & 6 \\
\hline Severe dysplasia & 15 & 13 & 1 & 1 \\
\hline Carcinoma in situ & 12 & 12 & 0 & 0 \\
\hline Invasive carcinoma & 7 & 7 & 0 & 0 \\
\hline
\end{tabular}

Table 2 Immunoperoxidase staining of 50 cytocentrifuge preparations with $O K T 9$ antibody

\begin{tabular}{|c|c|c|c|}
\hline Cytological diagnosis & Total & Positive staining & Negative staining \\
\hline $\begin{array}{l}\text { Normal } \\
\text { Mild dyskaryosis } \\
\text { Moderate dyskaryosis } \\
\text { Severe dyskaryosis } \\
\text { Malignant }\end{array}$ & $\begin{array}{r}11 \\
11 \\
10 \\
11 \\
7\end{array}$ & $\begin{array}{l}0 \\
1 \\
2 \\
6 \\
5\end{array}$ & $\begin{array}{r}11 \\
10 \\
8 \\
5 \\
2\end{array}$ \\
\hline
\end{tabular}

parations were unstained. The preparations which contained positive cells were stained in only some of the malignant or dyskaryotic cells present.

\section{Discussion}

Widespread immunohistochemical staining with OKT9 was seen in all sections of malignant epithelia and most sections of severely dysplastic epithelium. A lower incidence of staining was found in the cytocentrifuge preparations, in which many of the dyskaryotic and malignant cells were unstained. The cytocentrifuge preparations differ from the biopsy material in that they contain cells from a large area of cervix and may include cells from severe, moderate, or mild dysplasia. Although this may account for the variation in staining of the dyskaryotic cells, no such explanation can be given for the absence of staining in malignant preparations.

The appearance of immunohistochemical staining with OKT9 in the basal layers and in areas of immature squamous metaplasia in many of the epithelia examined cannot be fully explained. Gatter et $a^{14}$ have reported a similar finding in the basal layer of both the cervix and the epidermis. The occurrence of the transferrin receptor in the basal layers of squamous epithelium is in keeping with reports that the receptor is expressed on proliferating cells. ${ }^{15}$. In the present study, however, over half of the normal and mildly dysplastic epithelia did not show staining in these proliferating layers, which suggests that the occurrence of the receptor in the basal layers cannot be due exclusively to cell proliferation.

The widespread distribution of the transferrin receptors in both dysplastic and malignant cervical epithelia suggests that the OKT9 antibody is not a specific marker for malignancy. The antibody does distinguish, however, between normal cells above the basal layer and severely dysplastic and malignant cells, and it may therefore be possible to use OKT9 for screening cervical smears. The reduced staining seen in the cytocentrifuge preparations, however, sheds some doubt on such screening unless further work on cytological preparations produces staining comparable to that seen in the histological preparations. Screening techniques have been applied to cervical smears, ${ }^{15}$ but a consistent cell marker has yet to be found. ${ }^{16}$

The appearance of the transferrin receptor in certain dysplasias may be a reflection of an aggressive potential of cells and may signify a role for this marker in the prediction of malignancy. Twenty five patients were followed by colposcopy over a period of up to nine months to study the incidence of the transferrin receptor. Since the histopathology of the cervix varies gradually the duration of the study proved to be too short for any predictive role for the antibody to be determined. It will be necessary to study patients over several years if any such role for OKT9 is to be adequately investigated.

In this laboratory various antibodies (to $\alpha$ fetoprotein, human chorionic gonadotrophin, HLA $\mathrm{ABC}$, carcinoembryonic antigen, $\mathrm{Ca}$ antigen, and transferrin receptor) have been applied to cervical tissue. Of these, only OKT9 appears to distinguish between normal and abnormal epithelial cells.

This work was supported by the Cancer Research Campaign. We thank Professor W Page Faulk and Dr M Levine for their assistance and advice. We are grateful to our clinical colleagues, in particular to $\mathbf{M r}$ JWW Studd, Dr L Cardozo, Dr S Tuck, Dr D Rosenberg, and the nursing staff. We acknowledge the skilled technical assistance of Mr ET Davies, Miss J Deacon, Mrs G Harris, Mrs S Patel, and Mr A Perrin and also the photographic assistance of $\mathbf{M r}$ KW Davies and Mr RJ Senkus. We also thank Mrs NM Bennett for secretarial help.

\section{References}

'Sutherland R, Delia D, Schneider C, Newman R, Kenshead J, Greaves M. Ubiquitous cell-surface glycoprotein on tumour $\sigma$ cells is proliferation associated receptor for transferrin. Proc 
Natl Acad Sci USA 1981;78:4515-9.

${ }^{2}$ Galbraith GMP, Galbraith RM, Faulk WP. Immunological studies of transferrin and transferrin receptor of human placenta trophoblast. Placenta 1980;1:33-46.

${ }^{3}$ Enns CA, Shindelman JE, Tonik SE, Sussman HH. Radioimmunochemical measurement of the transferrin receptor in human trophoblast and reticulocyte membranes with a specific anti-receptor antibody. Proc Natl Acad Sci USA 1981;78:4222-5.

${ }^{4}$ Galbraith GMP, Galbraith RM, Faulk WP. Transferrin binding by human lymphoblastoid cell lines and other transformed cells. Cell Immunol 1980;49:215-22.

${ }^{5}$ Larrick JW, Creswell P. Modulation of cell surface iron transferrin receptors by cellular density and state of activation. $J$ Supramol Struct 1979;11:579-86.

${ }^{\circ}$ Hamilton TA, Wada HG, Sussman HH. Identification of transferrin receptors on the surface of human cultured cells. Proc Natl Acad Sci USA 1979;76:6406-10.

'Trowbridge IS, Omary MB. Human cell surface glycoprotein related to cell proliferation is the receptor for transferrin. Proc Natl Acad Sci USA 1981;78:3039-43.

${ }^{8}$ Faulk WP, Hsi BL, Stevens PJ. Transferrin and transferrin receptors in carcinoma of the breast. Lancet 1980;ii:390-2.

${ }^{9}$ Shindelman JE, Ortmeyer AE, Sussman HH. Demonstration of the transferrin receptor in human breast cancer tissue. Potential marker for identifying dividing cells. Int $J$ Cancer 1981;44:1301-10.

${ }^{10}$ Trowbridge IS, Domingo DL. Anti-transferrin receptor monoclonal antibody and toxin antibody conjugates affect growth of human tumour cells. Nature 1981;294:171-3.

" Pacsa AS, Kummerlander L, Pejtsik B, Krommer K, Pali K. Herpes simples virus specific antigens in exfoliated cervical cells from women with and without cervical anaplasia. Cancer Res 1976;36:2130-2.

12 Leif RC, Easter HN, Warters RL, Thomas RA, Dunlap LA, Austin MF. Centrifugal Cytology l. A qualitative technique for the preparation of glutaraldehyde-fixed cells for the light and scanning electron microscope. J Histochem Cytochem 1971;19:203-15.

${ }^{13}$ Haines HG, McCoy JP, Hofheinz DE, NG ABP, Nordqvist SRB, Leif RC. Cervical carcinoma antigens in the diagnosis of human squamous cell carcinoma of the cervix. $J$ Natl Cancer Inst 1981;66:465-74.

${ }^{14}$ Gatter KC, Brown G, Trowbridge IS, Woolston RE, Mason DY. Transferrin receptors in human tissues; their distribution and possible clinical relevance. J Clin Pathol 1983;36:539-45.

is Sincock AM, Middleton J, Moncrieff D. Towards an automated procedure for the qualitative cytological screening of cervical neoplasma. J Clin Pathol 1983;36:535-8.

${ }^{16}$ Lloyd JM, O' Dowd T, Driver M, Tee DEH. Immunohistochemical detection of $\mathrm{Ca}$ antigen in normal, dysplastic and neoplastic squamous epithelia of the human uterine cervix. J Clin Pathol 1984;37:14-20.

Requests for reprints to: $\mathrm{Dr} \mathrm{DEH}$ Tee, Department of Immunology, King's College Hospital Medical School, Denmark Hill, London SE5 8RX, England. 